\title{
A NEW SPECIES OF WINGED FRUIT FROM THE Miocene of Ecuador: Tipuana ecuatoriana (LEGUMINOSAE) ${ }^{1}$
}

\author{
ROBYN J. BURNHAM
}

Museum of Paleontology, University of Michigan, Ann Arbor, Michigan 48109-1079

\begin{abstract}
Tipuana ecuatoriana sp. nov. (Leguminosae; Dalbergieae), is described from winged fruits collected in Miocene sediments of the Loja and Nabon Basins of Ecuador. Extensive comparisons with families that include genera with similar samaroid fruits or disperal units led to recognition of legume affinities for the fossil. Based upon the texture of the fruit, the position of the style remnant, and the venation of the fruit wing, the fossil conforms to the extant monotypic genus, Tipuana, native to subtropical Bolivia and northwest Argentina, but widely cultivated in the subtropics. Tipuana, and thus the Dalbergieae as presently recognized, were present in South America prior to the establishment of permanent land connection between North and South America.
\end{abstract}

Cretaceous and Tertiary plant macrofossils from South America have been documented extensively by E. J. Romero and coworkers, (Romero and Hickey, 1976; Romero, 1986, 1993; Zamaloa and Romero, 1990) and by the early work of E. W. Berry $(1917,1921$, 1922, 1929a, c, 1934a, 1939). The earlier treatments are summarized frequently (Menendez, 1969; Raven and Axelrod, 1974; Gentry, 1982; Taylor, 1991) but new data from northern South America, or even revisions to the early northern paleobotanical work, are presented rarely (see Manchester and Kress, 1993 for a notable exception). Fossil fruits have received relatively little attention in these accounts but are important because of their potential to place fossil material directly into established taxonomies based on flower and fruit morphologies. In addition, fossil fruits give ecological information on disperal mechanisms in ancient plants. In light of recent biogeographic hypotheses proposed for plant families now distributed in both South America and Africa (Lavin and Luckow, 1993; Wendt, 1993) investigations of northern South American fossils can be brought to bear on hypotheses of present species richness, potential past migration routes, and sites of evolutionary diversification. This paper presents new information on Andean floras from the Miocene of Ecuador, with detailed information on a single taxon represented by fruit material.

Plant fossils from the Ecuadorian Andes were first reported in an early publieation on the Loja Basin by Wolf and vom Rath (1876). Subsequently, H. Engelhardt (1895) published a systematic account of plant fossils collected in the Loja Basin. E. W. Berry (1929b) presented another brief account of plant fossils from the Loja Basin, adding 20 angiosperms and two ferns to Engelhardt's original 42 species of fungi, mosses, ferns, and angiosperms. In 1934 Berry published a brief account of

\footnotetext{
'Manuscript received 18 January 1995; revision accepted 25 April 1995

The author thanks Rupert Barneby, Victor Call, Patrick Herendeen, Matt Lavin, Steven R. Manchester, and Bruce H. Tiffney for their advice on aspects of the manuscript; Bonnie Miljour for rendering the fine drawings of many winged fruits; and Dr. Luis Albuja, Escuela Politecnica Nacional, Quito for assistance. This research was supported by a grant to Richard Madden, Robyn Burnham, and Carl Swisher, III from the National Geographic Society.
}

purportedly Pliocene fossils from the Cuenca Basin (Berry, 1934b). In 1945, Berry revised and summarized all plant remains that had been recovered to that time from three southern Ecuadorian Basins: Cuenca, Catamayo, and Loja, with the majority of taxa coming from extensive collections in Loja. Collections in all cases were made for systematic purposes, so paleoecological inferences are limited based on the floras now at hand. Leguminous fruits and leaflets are represented by 16 species (of a total of 64 angiosperm species) in Berry's 1945 list. Two genera of winged fruits (Hiraea and Banisteria) are figured by Engelhardt, who placed these, apparently correctly, in the Malpighiaceae. No additional winged disseminules are figured by Berry.

The Leguminosae is one of the largest extant flowering plant families, with $\approx 650$ genera and $\approx 17,500$ species distributed worldwide (Polhill, Raven, and Stirton, 1981; Rundel, 1989). Fossil wood and pollen of legumes are reported from sediments as old as the Late Cretaceous (Muller, 1981; Giraud and Lejal-Nicol, 1989). Reports of wood, leaves, fruits, flowers, and pollen in Tertiary sediments are common (reviewed in Herendeen, Crepet, and Dilcher, 1992). Given the current world-wide distribution and species richness of the three subfamilies of the Leguminosae, any number of hypotheses of sites of origin, migration and centers of diversity can be made, but none can be unequivocally substantiated based on modern data alone. The addition of data on fossil plant distributions derived from well-dated sediments can provide excellent information on the potential sites of diversification and the causes of present phytogeographic distributions.

Fruits of the Leguminosae usually are recognized by their characteristic single-carpellate pod and included seeds. The fruit, when dehiscent, is called a legume (example: Cassia emarginata), and when indehiscent, a camara (Spjut, 1994; example: Tamarindus indica). Other fruit types are considerably less common in the family, but can include the cypsela, diclesium, lomentum, samara, and utricle. These more rare fruit types in the legume family are particularly diagnostic as fossils and one of them, the samara, is the subject of this paper.

Samaras or samara-like fruits (including the samaretum and samarium of Spjut, 1994) are included in a diverse 
TABLE 1. Families of Angiosperms that include genera with some species dispersed by samaroid fruits.

\begin{tabular}{lll}
\hline \hline Aceraceae & Magnoliaceae & Sapindaceae \\
Anacardiaceae & Malpighiaceae & Trigoniaceae \\
Celastraceae & Phytolaccaceae & Ulmaceae \\
Combretaceae & Polygalaceae & Violaceae \\
Leguminosae & Rhamnaceae & \\
\hline
\end{tabular}

assortment of angiosperm families (Table 1), which as a group do not represent the single evolutionary origin of a single-seeded winged disseminule within the angiosperms. Although derived from different floral and carpel morphologies, the samara-like fruits have remarkable morphological similarities at the time of dispersal. Three basic types of samaroid fruits are recognized on the basis of number and degree of fusion of carpels (Spjut, 1994): samara, samarium, and samaretum. Families that include samaroid fruits have converged on the fruit morphology in a variety of ways. Families whose flowers bear separate, multiple carpels produce fruits that break up at maturity (samaretum), dispersing many individual winged carpels (example: Liriodendron). Families with fused, multicarpellate ovaries produce a samarium that can be dispersed in two ways: as a whole, with intact bi- or trilateral wings (example: Serjania), or divided at dispersal, yielding individual carpels dispersed as unilateral oneseeded "schizocarps" (example: Acer). Finally, fruits composed of a single winged carpel, dispersed without dehiscence, form the true samara fruit (examples: Centrolobium, Ulmus).

The autogyro samara is a particularly stable dispersal mechanism in turbulent air (Green, 1980; Augspurger, 1986), and thus it is not surprising that several families have converged upon this solution. Nonrolling asymmetrical autogyros (e.g., Acer, Macherium) have a trajectory with a high angular velocity and low terminal velocity and are dispersed further from the source plant (Green, 1980; Augspurger, 1986), relative to symmetrical rolling samaras (e.g., Liriodendron, Fraxinus). The morphological comparisons made in this report are all relevant to the rolling, asymmetrical autogyro samara, found in at least eight families.

\section{LOCALITIES, MATERIALS, AND METHODS}

Two specimens of a distinctive winged fruit were found in sediments of the Iguincha and San Cayetano Formations in the Nabón and Loja Basins, respectively, of Ecuador (Fig. 1). The specimens (Figs. 2-5) are preserved as isolated impressions, without physical attachment to other organs, and with little or no retained organic material. Within the basins, plant impressions are preserved in fine-grained lacustrine and paludal facies, and are associated with vertebrate fossils (under investigation by J. Lundgren [fish], and R. Madden [mammals]) and invertebrates (Bristow, 1973, 1976, 1982). Until recently, the basis for the Miocene age was biostratigraphy. Recent radiometric dates on sediments from the Loja and Nabón Basins, and the Cuenca Basin to the north, range from 6 to 19 million years (Ma) (Winkler et al., 1993; Madden et al., 1994). Recent studies of sediments from the Nabón Basin (Hungerbühler et al., 1995) have combined fission-track and paleomagnetic analyses to construct a chronology that places the Inguincha Formation between 8.5 and 7.9 Ma. These detailed studies have constrained the age of plant remains in the Nabón basin as Middle to Late Miocene. Additional samples from associated tuffs, ignimbrites, and other proximal volcanic

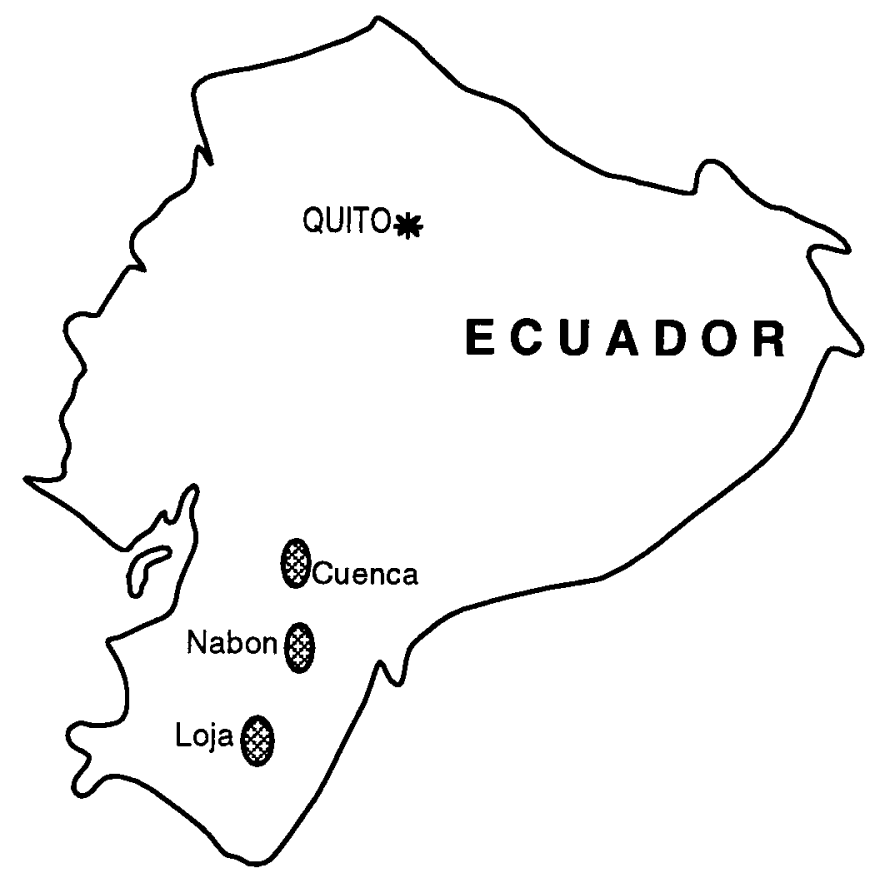

Fig. 1. Location of three basins in the Ecuadorian Andes mentioned in the text.

facies have been collected to provide further radiometric assessment of these basins, particularly the Loja Basin.

Plant fossils and modern comparative material were studied using a Zeiss SV-8 stereomicroscope and photographed using a Nikon N6000 camera with a Nikkor $55 \mathrm{~mm}$ Micro AF lens. Drawings of fossil and modern fruits were made using a Wild stereomicroscope and camera lucida. Herbarium specimens of extant plants were borrowed from Missouri Botanical Garden (MO), Field Museum of Natural History (F), New York Botanical Garden (NY), and University of Michigan Herbarium (MICH).

Comparisons of the fossil material were made with families that include genera bearing samaras or samara-like fruits. Although families were included whose fruits are not strictly samaras in the terminology of Spjut (1994), it is possible that, with dispersed fruits like the fossil, a half samarium could be mistaken for a samara. Those families that include genera whose samaras or samara-like fruits are composed of basal seed(s) and a unilateral distal wing are included in a character comparison in Table 2 . The characters tabulated include features clearly observable on the fossil fruits and considered to be distinctive of the fruits. Drawings of the most similar genera of seven of these families are illustrated in Fig. 6.

Genera with basal-seeded samaras and lateral wings in the Leguminosae were tabulated by Augspurger (1989) in a review of wind-dispersed fruits of genera of the family. She found two genera in the Caesalpinoideae subfamily and nine genera in the Faboideae (= Papilionoideae) subfamily that included basal-seeded samaras. No additional valid genera that include species with basal-seeded, unilateral-winged samaras were found in the Leguminosae. These 11 genera are listed in Table 3 to facilitate comparison of morphological characteristics with those of the fossil. The nine most similar genera of these legumes are illustrated in Fig. 7.

\section{RESULTS}

Comparisons of families including genera with basalseeded, lateral-winged samaroid fruits-Twelve characters of mature fruits were compared across several fam- 


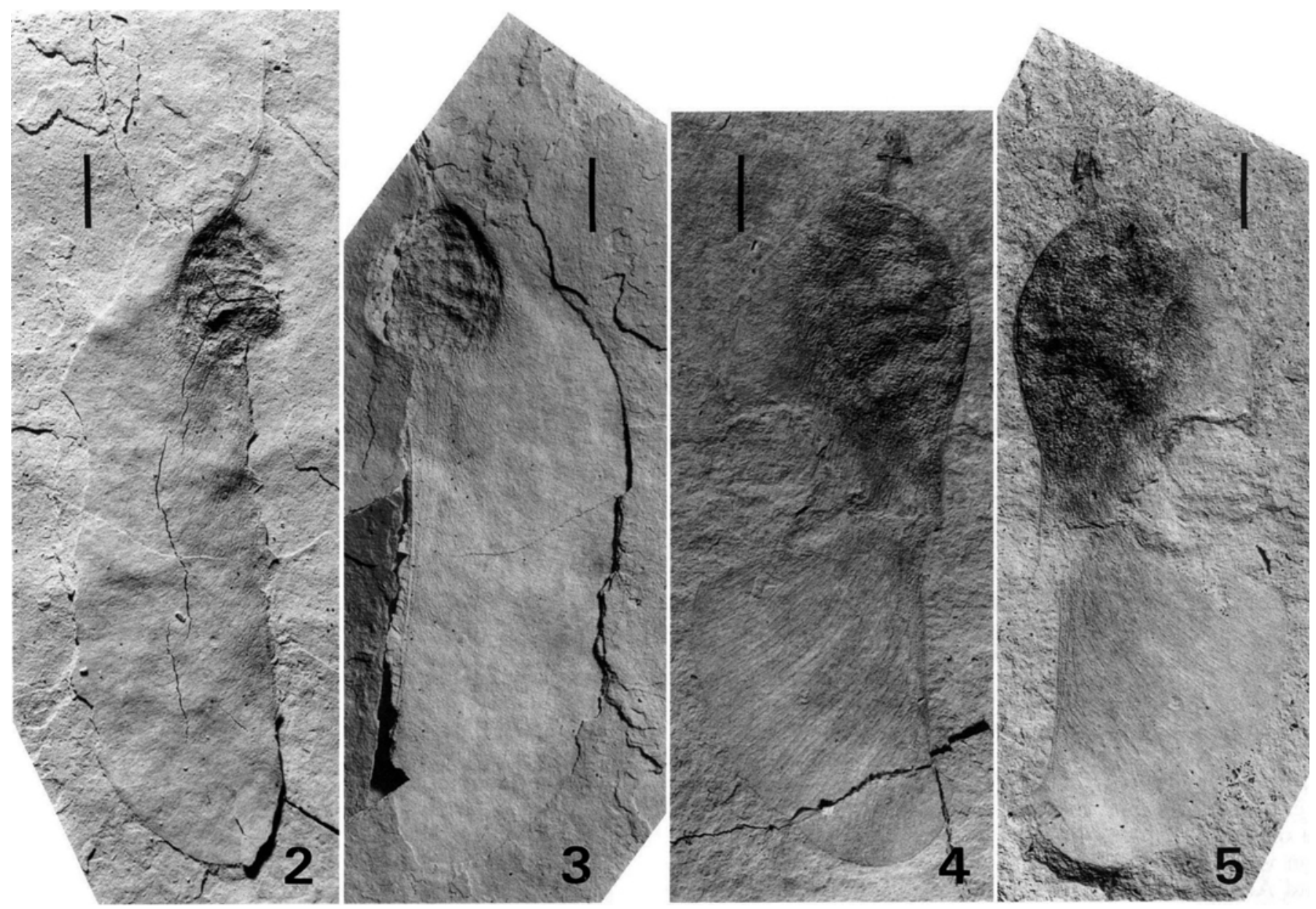

Figs. 2-5. Fossil fruits from Miocene sedimentary basins of Ecuador. 2-3. Winged fruit from Loja Basin. 4-5. Winged fruit from Nabón Basin. All bars $=0.5 \mathrm{~cm}$.

TABLE 2. Distribution of character states of winged fruits in selected genera of nine families of angiosperms and in the Miocene fossil specimens from Ecuador. ${ }^{a}$

\begin{tabular}{|c|c|c|c|c|c|c|c|c|c|c|c|c|c|}
\hline \multirow[b]{2}{*}{ Families } & \multirow[b]{2}{*}{ Genera } & \multicolumn{12}{|c|}{ Characteristics } \\
\hline & & 1 & 2 & 3 & 4 & 5 & 6 & 7 & 8 & 9 & 10 & 11 & 12 \\
\hline Aceraceae & Acer & - & - & + & $\mathrm{C}$ & B & $\mathrm{D}$ & $\mathrm{S}(\mathrm{W})$ & $-(+)$ & $\mathbf{R}$ & C & $\mathrm{P}$ & $\mathrm{P}$ \\
\hline Anacardiaceae & Loxopterygium & + & - & - & $\mathrm{C}$ & $\mathrm{M} / \mathrm{B}$ & S & W & - & F & C & $\mathrm{P}$ & $\mathrm{P}$ \\
\hline \multirow[t]{4}{*}{ Malpighiaceae } & Banisteriopsis & + & - & + & $\mathrm{C}$ & $\mathbf{M}$ & $\mathrm{D}$ & W & $-{ }^{*}$ & $\mathrm{R}$ & $\mathrm{C}$ & $\mathrm{S}$ & $\mathrm{P}$ \\
\hline & Janusia & + & - & - & $\mathrm{C}$ & B & $\mathrm{D}$ & W & - & $\mathrm{R}$ & $\mathrm{C}$ & $\mathrm{P}$ & $\mathrm{P}$ \\
\hline & Stigmaphyllon & + & - & + & $\mathrm{C}$ & B & $\mathrm{D}$ & W & - & $\mathbf{R}$ & $\mathrm{C}$ & $\mathrm{P}$ & $\mathbf{P}$ \\
\hline & Heteropteris & $+1-$ & - & + & C & $\mathrm{B} / \mathrm{N}$ & S/D & W/S & - & $\mathrm{R}$ & $\mathrm{C}$ & $\mathrm{P} / \mathrm{R}$ & $\mathrm{P}$ \\
\hline Polygalaceae & Securidaca & + & $+1-$ & - & C & $\mathbf{M}$ & D & $\mathrm{S}$ & $+1-$ & $\mathbf{R}$ & C & $\mathrm{P} / \mathrm{R}$ & $\mathbf{P}$ \\
\hline \multirow[t]{2}{*}{ Sapindaceae } & Thinouia & - & + & + & $\mathrm{C}$ & $\mathrm{N}$ & $\mathrm{D}$ & W & + & $\mathbf{R}$ & C & $\mathrm{P}$ & P \\
\hline & Thouinidium & - & - & + & C & $\mathbf{N}$ & $\mathrm{S}$ & W & + & $\mathbf{R}$ & C & $\mathbf{R}$ & $\mathbf{R}$ \\
\hline Trigoniaceae & Trigoniastrum & $+(-)$ & - & + & $\mathrm{C}$ & A & $\mathrm{S}$ & W & - & $\mathrm{F}$ & I & $\mathbf{R}$ & $\mathbf{R}$ \\
\hline Miocene fossils & & + & + & - & $\mathrm{C}$ & A & $\mathrm{S}$ & W & + & $\mathbf{R}$ & $\mathrm{C}$ & $\mathrm{P}$ & $\mathbf{P}$ \\
\hline
\end{tabular}

a Characters and states-1. Calyx remnant: + (present), - (absent); 2. Stipe: + (present), - (absent); 3. Attachment Surface: + (present), (absent); 4. Texture: W Woody, C Chartaceous; 5. Style Position: Basal, Apical, Mid, None; 6. Wing Tip Venation: Spread, Deflexed, Mid, Reticulate; 7. Backbone Venation: Weak, Strong; 8. Wing on Seed Body: + (present), - (absent); 9. Seed Cross-Section: Round, Flat; 10. SeedWing Distinction: Clear, Indistinct; 11. Seed Ornamentation: Parallel, Reticulate, Spiny; 12. Wing Venation: Parallel, Reticulate. 
TABLE 3. Distribution of character states of basal seeded, unilaterally winged fruits in eleven genera of Leguminosae and in the Miocene fossil specimens from Ecuador. See Table 2 for definitions of characters and state codes.

\begin{tabular}{|c|c|c|c|c|c|c|c|c|c|c|c|c|}
\hline \multirow[b]{2}{*}{ Genera } & \multicolumn{12}{|c|}{ Characteristics } \\
\hline & 1 & 2 & 3 & 4 & 5 & 6 & 7 & 8 & 9 & 10 & 11 & 12 \\
\hline Centrolobium & + & $+1-$ & - & W & M & D & W & + & $\mathbf{R}$ & $\mathrm{C}$ & $\mathrm{S}$ & $\mathbf{P}$ \\
\hline Luetzelburgia & + & $+1-$ & - & W & $\mathrm{A}$ & $\mathrm{D}$ & $\mathbf{S}$ & + & $\mathrm{R}$ & $\mathrm{C}$ & $\mathbf{P}$ & $\mathbf{P}$ \\
\hline Machaerium & + & + & - & $\mathrm{C}$ & A & $\mathrm{M} / \mathrm{R}$ & W & $+1-$ & $\mathrm{R} / \mathrm{F}$ & $\mathrm{C} / \mathrm{I}$ & $\mathrm{R}$ & $\mathbf{R}$ \\
\hline Nissolia & + & + & - & $\mathrm{C}$ & $\mathrm{A}$ & $\mathbf{R}$ & W & + & $\mathrm{R}$ & $\mathrm{C}$ & $\mathrm{R}$ & $\mathbf{P}$ \\
\hline Pterogyne nitens & + & + & - & $\mathrm{C}$ & $\mathbf{M}$ & (D) M & W & - & $\mathrm{F}$ & $\mathrm{C}$ & $\mathrm{R}$ & $\mathbf{P}$ \\
\hline Pterolobitum & + & + & - & $\mathrm{C}$ & A & D & W & - & $\mathrm{F}$ & $\mathrm{C}$ & $\mathrm{R}$ & $\mathbf{P}$ \\
\hline Paramachaerium & + & - & - & $\mathrm{C}$ & A & $\mathrm{M} / \mathrm{R}$ & W & - & $\mathbf{R}$ & $\mathrm{C}$ & $\mathbf{P}$ & P/R \\
\hline Sweetia & + & + & - & $\mathrm{C}$ & A & $\mathrm{D}$ & $S$ & + & $\mathbf{R}$ & $\mathrm{C}$ & $\mathbf{P}$ & P/R \\
\hline Tipuana & + & + & - & $\mathrm{C}$ & A & $\mathrm{S}$ & W & + & $\mathbf{R}$ & $\mathrm{C}$ & $\mathbf{P}$ & $\mathbf{P}$ \\
\hline Vatairea & - & + & - & W & A & D & $\mathbf{S}$ & + & $\mathbf{R}$ & $\mathrm{C}$ & $\mathrm{P}$ & $\mathbf{P}$ \\
\hline Vataireopsis & + & + & - & $\mathbf{W}$ & A & $\mathrm{D}$ & $S$ & + & $\mathbf{R}$ & $\mathrm{C}$ & $\mathrm{P}$ & $\mathbf{P}$ \\
\hline Miocene fossils & + & + & - & $\mathrm{C}$ & A & $S$ & W & + & $\mathbf{R}$ & $\mathrm{C}$ & $\mathrm{P}$ & $\mathbf{P}$ \\
\hline
\end{tabular}

ilies that include winged fruits (Table 2; Fig. 6). The single most informative feature of the fossil specimens in determining their phylogenetic position at the family level is the absence of any attachment surface (character 3; Table 2) to which the fruit may have been fused during ontogeny to other carpels or fruit parts. Attachment surfaces are usually indicated by a distinctive, straight margin on the fruit wing or seed body but may also be suggested by a calyx remnant on the mature fruit. This feature eliminates possible placement of the fruit in the basal-seeded, multicarpellate Sapindaceae, Malpighiaceae, Trigoniaceae, and Aceraceae. In addition, the presence of a calyx remnant and short stipe (characters 1 and 2, Table 2 ) on the fruit help eliminate the possibility of comparison with the mature winged fruits of the Phytolaccaceae and Anacardiaceae. Families that do bear characters 1-4 and $8-12$ (Table 2) in states similar to the fossil in at least one genus include only the Polygalaceae and Leguminosae. Both of these families include genera whose samaras closely match the morphological features observable in the fossil specimens. Fruits of Securidaca (Polygalaceae) bear a style remnant at the top of the seed body of the fruit, whereas in the fossils the fruit wing bears the style remnant at its apex. In addition, in all of the specimens of Securidaca examined, the venation in the "backbone" of the wing is much stronger than that preserved in the fossil (character 7, Table 2). Although the Leguminosae is a large, variable family, all characters present in the fossil are found in combination in at least some of the unilateral, basal-seeded fruits. Further comparison is made only with the Leguminosae.

Comparisons of genera of Leguminosae with basalseeded, lateral-winged samaroid fruits-The same 12 characters used in the comparison of the fossil material to extant families were used to compare the fossil spec- imens to genera within the Leguminosae (Table 3; Fig. 7). The single most informative feature of the fossil in these comparisons is the course of the parallel veins of the fruit wing as the veins approach the distal portion of the wing (character 6; Table 3). In the fossil the veins spread relatively evenly over the wing tip, with some of the veins closest to the backbone of the fossil following an almost straight course. Veins of the opposite side of the wing curve downward at the wing tip, enervating the lower part of the wing. Only in the genus Tipuana is this character state present in combination with a parallel wing venation pattern. Style position alone readily distinguished Tipuana and the fossil from a few genera within the Leguminosae (Centrolobium, Pterogyne). The strength of the venation in the backbone of the wing is also helpful in distinguishing Tipuana from genera such as Luetzelbergia, Sweetia, Vatairea, and Vataireopsis. The presence of reticulate venation in the wing and sometimes on the seed body is useful in distinguishing $\mathrm{Ma}$ chaerium, Pterogyne, Paramachaerium, Pterolobium, and some species of Vatairea. All characters noted for the fossil material in Table 3 are present in the modern genus Tipuana.

The fossil is thus determined to be a member of the monotypic extant genus Tipuana (Rudd, 1974). Tipuana is native today to subtropical forests of Bolivia and northwestern Argentina, and has been introduced horticulturally in subtropical climates around the world. Although very little difference can be seen between the fossil fruits and fruits of extant Tipuana tipu, the strength of the venation of the seed body is weaker in the fossils than in the modern specimens examined. In addition, the length of the stipe between seed and calyx remnant is slightly shorter in the two fossils than in extant specimens of Tipuana tipu. Interestingly, the specimen from Loja (Fig. 3) shows three ridges on the seed chamber, which may

Fig. 6. Line drawings of examples of genera with winged fruits from seven families of angiosperms with winged fruits. Species used for the drawings are: Acer saccharinum. Banisteriopsis muricata, Trigoniastrum hypoleucum, Tipuana tipu, Gallesia gorarema, Securidaca ovalifolia, Seguieria sp. (Paraguay), Thouinia paraguaiensis, and Thouinidium decandrum. All bars $=1 \mathrm{~cm}$.

Fig. 7. Line drawings of examples of genera of Leguminosae with basal-seeded, unilaterally winged fruits. Species used for the drawings are: Luetzelburgia auriculata, Machaerium chiapense, Nissolia sp. (Mexico), Paramachaerium schunkei, Pterogyne nitens, Pterolobium stellatum, Tipuana tipu, Sweetia fruticosa, and Vatairea lundellii. All bars $=1 \mathrm{~cm}$. 


\section{MODERN FRUITS VARIOUS FAMILIES}

ECUADORIAN MIOCENE FRUITS

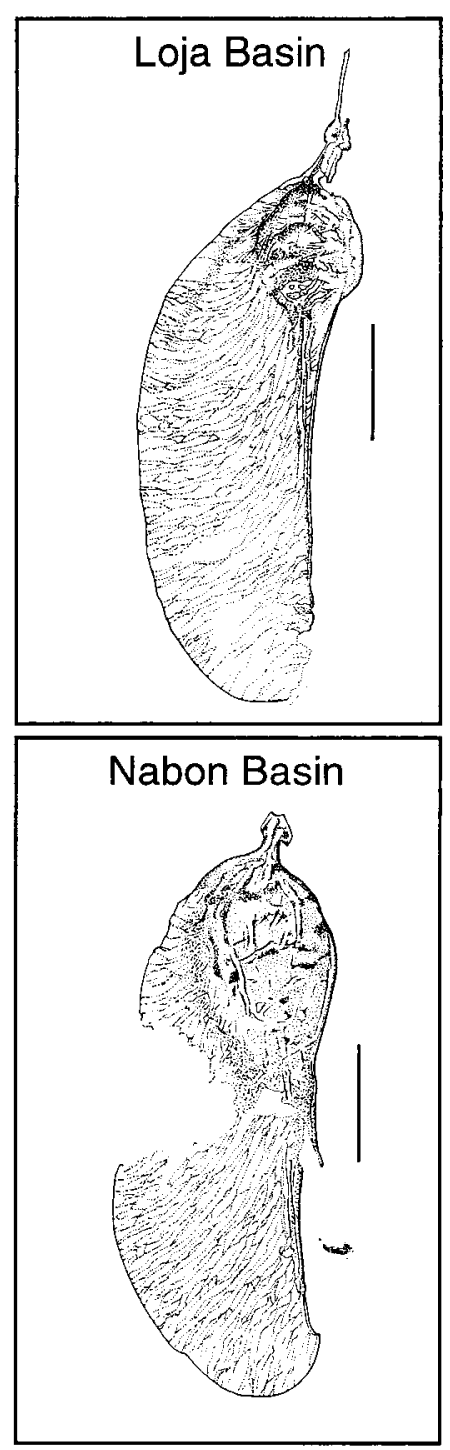

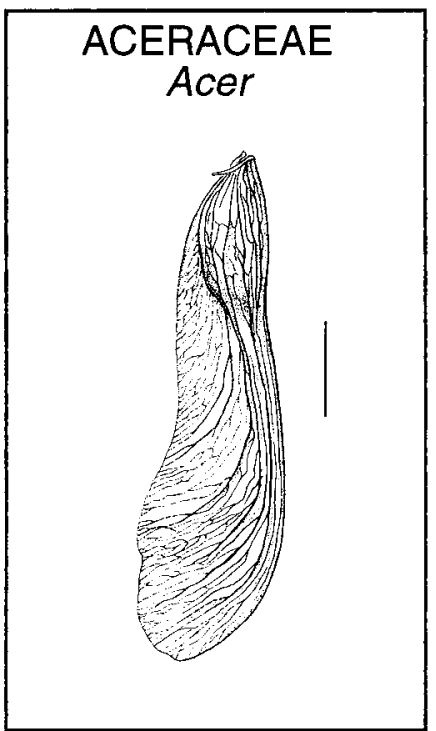
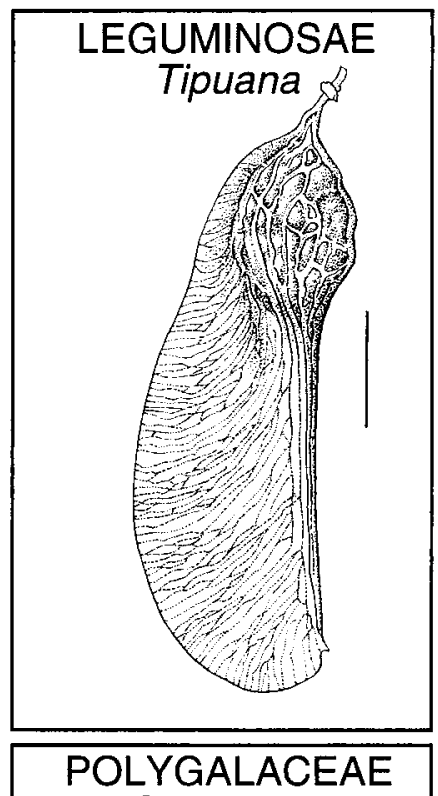
Securidaca

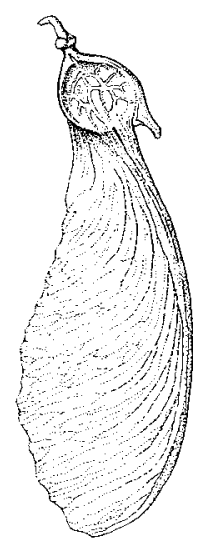

MALPIGHIACEAE Banisteriopsis
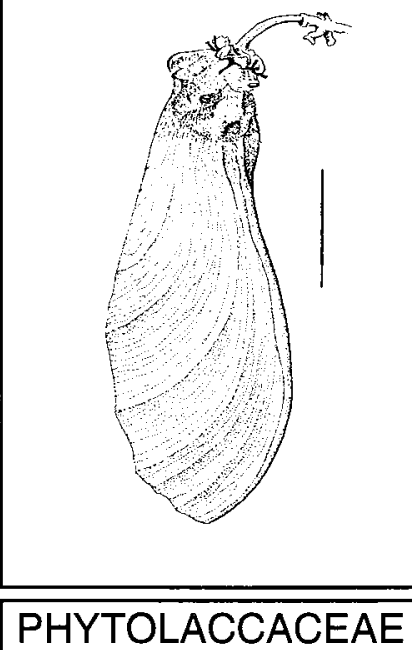
Gallesia

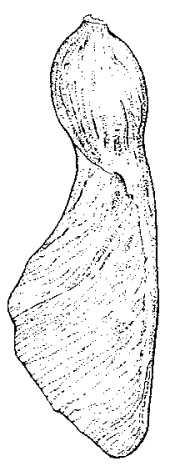

SAPINDACEAE Thinouia

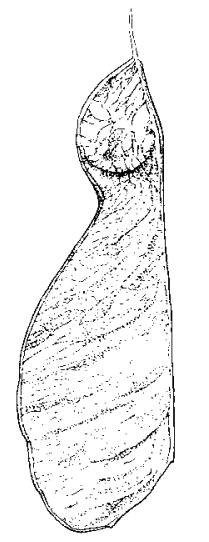

TRIGONIACEAE

Trigoniastrum

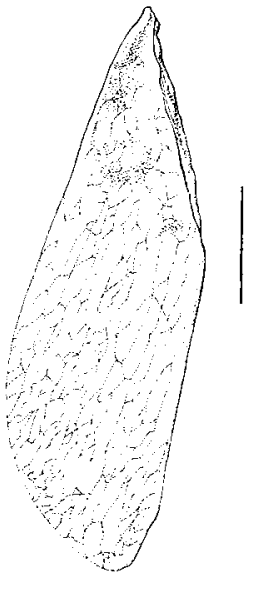

PHYTOLACCACEAE Seguieria

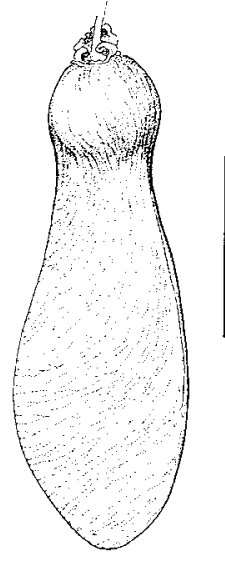

SAPINDACEAE Thouinidium

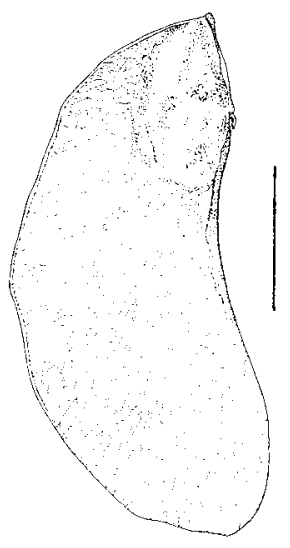


MODERN LEGUME FRUITS

ECUADORIAN MIOCENE FRUITS
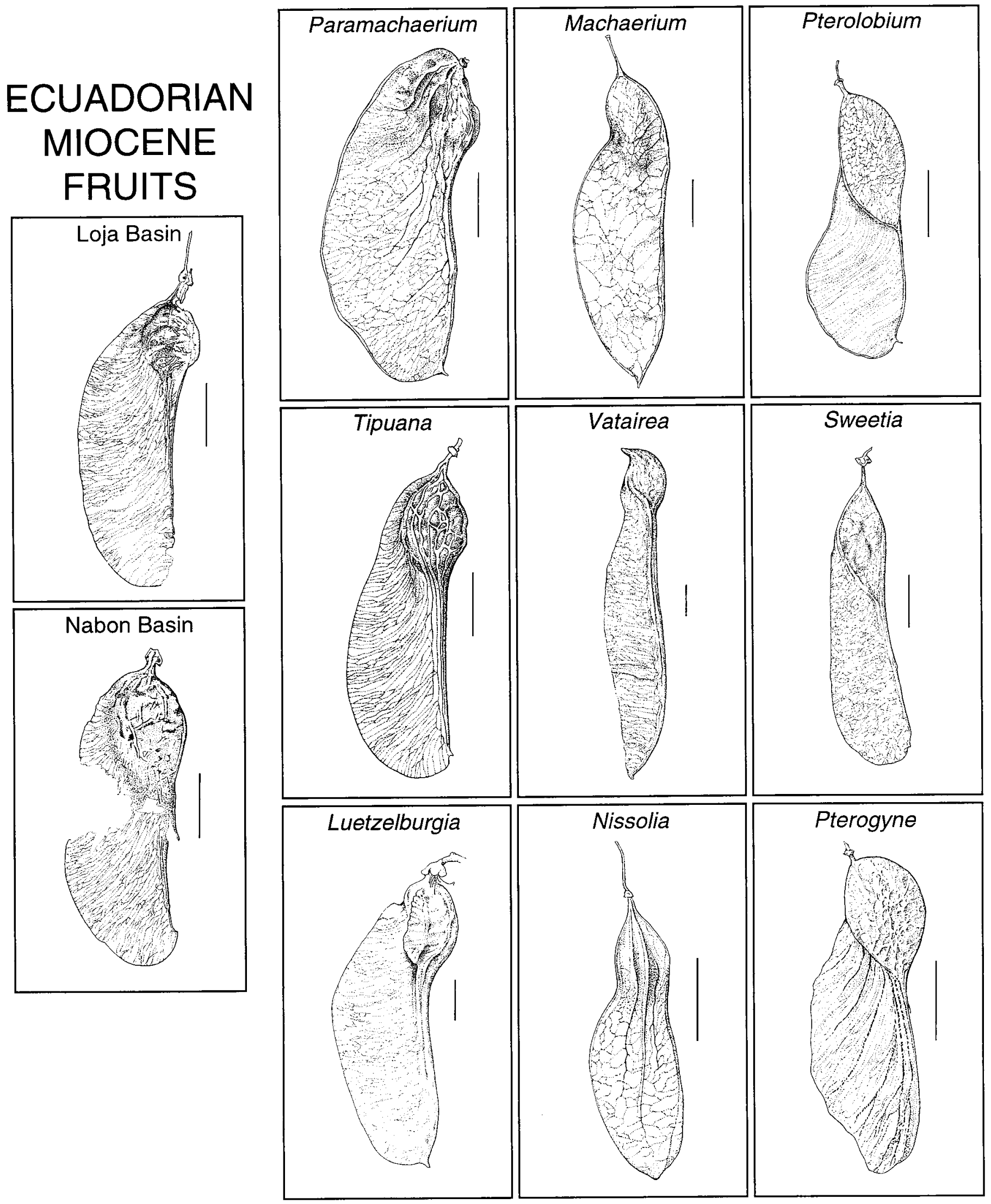
correspond to the occasional presence of more than one (up to three) embryos in fruits of T. tipu (Burkart, 1952). Without additional material from the deposits in Ecuador, it would be difficult to determine whether these proposed specific differences simply represent differences in maturity of the fruit. Because no extant specimens examined include the differences stated above, the fossil is recognized as distinct from the modern species. A new species is recognized, Tipuana ecuatoriana, with distribution in Miocene sediments of the Loja and Nabón basins.

\section{SYSTEMATICS}

Family_Leguminosae; Subfamily_Papilionoideae; Tribe-Dalbergieae Tipuana (Benth.) Benth.

Tipuana ecuatoriana Burnham sp. nov. Figs. 2-5.

Description-Both fossil fruits are $46 \mathrm{~mm}$ long including the wing, and their widths are 13.5 and $16 \mathrm{~mm}$ at the widest point on the seed chamber. The wing is 34 and $28 \mathrm{~mm}$ long from the distal margin of the seed chamber to the distal margin of the wing. The fruit is composed of a basal seed chamber and distal wing, with style remnant at the distal end of the wing, thus the wing represents the expanded, distal portion of the ovary, including the style. The wing is faintly parallel veined, with only slightly stronger veins investing the backbone of the wing. Individual veins fork from three to six times in their course. Venation of the wing is distinctly spread at the distal end of the wing so that individual veins may end either on the shorter, distal end of the wing or on the longer, lateral margin of the wing. The specimen from Nabón clearly shows a remnant of the stigma on the distal margin of the wing (Figs. 4, 5). A narrow extension of the wing extends proximally along the seed chamber fully three-quarters of the way from the distal portion of the seed to the point of attachment of the seed chamber to the stipe. Although the seed chamber and wing are clearly distinct from one another, there is no line of demarcation between the two. The surface of the seed chamber is faintly parallel-veined, with slight sculpturing on the surface of the chamber. The specimen from Loja shows transverse furrowing in the seed chamber, which may correspond to separate seeds inside the chamber (Fig. 3). The seed chamber appears to have been rounded to oblong in cross section, although sufficient carbonaceous material to confirm this interpretation is lacking. The seed chamber is elongated distally, forming a blunt apex at the distal portion of the chamber. The fruit is short-stipitate, the stipe $3 \mathrm{~mm}$ in length. The remnant of a caylx is present above the stipe, and in the specimen from Loja, a portion of the peduncle $(\approx 2 \mathrm{~mm})$ is also present. The fossil species can be distinguished from modern Tipuana tipu by the weaker backbone and shorter stipe on the fossil material. The nine million year minimum age difference between the fossil and modern specimens is not invoked here to support a species distinction. If further collections from these two basins reveal that the distinctions cited above are indicative of age of development of the fruits, rather than species distinctions, the fossil and modern material should be synonomized.

Localities: The fossils are from the Iguincha and San
Cayetano Formations of the Nabón and Loja Basins, respectively.

Holotype: Nabón EPN 4413.

Paratype: Loja EPN 4420.

Number of specimens examined: two, each with part and counterpart preserved.

\section{DISCUSSION}

Biogeographic relationships between South America and both Africa and North America have geological and biological importance. Changes in the floral and faunal composition of continents through time have allowed estimates of the sequence of continental collisions and separations, and have thus played a key role in the development of plate tectonic theory (Seward, 1931; Plumstead, 1961; Arnold, 1973; Briggs, 1987). More recently, the details of migrations between the continents and the effect of isolation of biotas have been of interest to biologists working on a wide range of organisms (Stehli and Webb, 1985; Goldblatt, 1993; Wyss et al., 1993). Of particular interest has been the influence of an invading flora or fauna on the resident biota, the phylogenetic relationships among closely related organisms that inhabit two or more of these continents, the timing of diversification of a biota and continental configuration, and the coevolutionary relationships that are found on each continent. Fossil evidence has an important place in the scenarios built to explain these biological patterns. In the case of the Great American Interchange Hypothesis (Marshall et al., 1979, 1982; Marshall, 1981, 1985), fossils were used to document the timing of appearance of migrant faunal elements in South America and their role as competitors from North America. In Vrba's Habitat Theory (Vrba, 1993), direct faunal evidence is summoned to support the idea that habitat changes stimulated faunal replacement, as opposed to a strict competitive-based replacement.

Theories of refugia, dynamic turnover, and nonequilibrium that are used to explain forest tree richness across latitudinal gradients also incorporate temporal assumptions that may be tested using the plant fossil record. The palynological record has been used in South America by Absy (1985), Bush et al. (1990), Wijninga and Kuhry (1990), Graham (1992), Hooghiemstra (1993), and Van der Hammen and Absy (1994) to interpret vegetation changes in the Pliocene and Pleistocene with interesting and not entirely concordant results. Plant macrofossils (wood, leaves, flowers, fruits) are relevant to these discussions because the taxonomic resolution of an individual macrofossil specimen is often much better than that of pollen. Ecological specificity, particularly with respect to altitudinal tolerance is more pronounced at the species level than at the generic level, so the taxonomic resolution is of great importance in refugial theories. The degree of resolution demanded by the hypotheses, particularly those relevant to current angiosperm-dominated forests, can be increased by reference to the macrofossil plant record.

The fossil fruits from the Miocene Ecuadorian basins are apparently mature, dispersed fruits. They are easily distinguished as fruits, rather than seeds by the presence of the calyx remnant that is attached to the stipe at the 
proximal end of the fruit. None of the leaves collected to date in the same deposits appear to be allied with those of extant Tipuana, however specimen numbers are still small. The present subtropical distribution of the genus suggests that conditions favorable for growth of subtropical plants existed in southern Ecuador during the late Miocene. The wide cultivation of the extant species suggests, however, that the plant may be robust under conditions that are not identical to those experienced in its present, natural range. As far north as Santa Barbara, California, Tipuana tipu produces viable seeds that germinate naturally under garden conditions ( $\mathrm{S}$. Baumgartner, personal communication, 1995).

Tipuana generally is placed in the Dalbergieae tribe of the subfamily Papilionoideae of the Leguminosae. The Dalbergieae was suggested as a basal clade within the family, probably arising from the Sophoreae (Polhill, 1981). This hypothesis, however, is not accepted by all legume systematists (M. Lavin, personal communication, 1995). A well-supported phylogeny of the legumes is needed to evaluate the significance of individual legume taxa in South America prior to the land bridge emergence. In the absence of such a phylogeny, the primary significance of legume fossils in South America may very well be in documenting the distinctiveness of the South American flora at the generic level during the Miocene. This report presents information on a legume taxon that has never been reported in sediments of any age from North America. Comparisons of the taxonomic composition of well-dated floras from North and South America must be made to determine whether the land bridge was functioning as a migrational filter for land plants during the early and middle Cenozoic.

\section{LITERATURE CITED}

ABsy, M. L. 1985. Palynology of Amazonia: the history of the forests as revealed by the palynological record. In G. T. Prance and $\mathrm{T}$. Lovejoy [eds.], Key environments of Amazonia, 72-82. Pergamon, New York, NY.

Arnold, C. A. 1973. Fossil plants and continental drift. Birbal Sahni Memorial Lecture 1: 1-11.

AugsPURGER, C. K. 1986. Morphology and dispersal of wind-dispersed diaspores of neotropical trees. American Journal of Botany 73: 353-363.

1989. Morphology and aerodynamics of wind-dispersed legumes. In C. H. Striton and J. L. Zarucchi [eds.], Advances in Legume Biology, Monographs in systematic botany, Missouri Botanical Garden 29, 451-466.

Berry, E. W. 1917. Fossil plants from Bolivia and their bearing upon the age of uplift of the eastern Andes. Proceedings of the United States National Museum 54: 103-164.

- 1921 . Tertiary fossil plants from Venzuela. Proceedings of the United States National Museum 59: 553-579.

1922. Pliocene plants from eastern Bolivia. John Hopkins Studies in Geology 4: 145-202.

- 1929a. Tertiary fossil plants from Colombia, South America. Proceedings of the United States National Museum 75: 9-12.

- 1929b. The fossil flora of the Loja Basin in southern Ecuador. John Hopkins Studies in Geology 10: 79-134.

. 1929c. Early Tertiary fruits and seeds from Belen, Peru. John Hopkins Studies in Geology 10: 137-182.

- 1934a. Extension of range of Attalea olssoni. Journal of the Washington Academy of Sciences 24: 447-448.

. 1934b. Pliocene in the Cuenca Basin of Ecuador. Journal of the Washington Academy of Sciences 24: 184-186.

. 1939. Fossil plants from the state of Anzoategui, Venezuela. John Hopkins Studies in Geology 13: 137-155.
1945. Fossil floras from southern Ecuador. John Hopkins Studies in Geology 14: 93-154.

BRIGGS, J. C. 1987. Biogeography and plate tectonics. Elsevier, Amsterdam.

BRISTOW, C. R. 1973. Guide to the geology of the Cuenca Basin, southern Ecuador. Ecuadorian Geological and Geophysical Society, Quito.

1976. On the age of the Nabón Formation, Ecuador. Newsletter Stratigraphy 5(2/3): 104-107.

1982. The stratigraphical paleontology of the Tertiary nonmarine sediments of Ecuador. Bulletin of Carnegie Museum of Natural History 19: 5-53.

BuRKART, A. 1952. Leguminosas Argentinas: silvestres y cultivadas. Acme Agency, Buenos Aires.

Bush, M. B., P. A. Colinvaux, M. C. Wiemann, D. R. Piperno, and Kam-Biu Liu. 1990. Late Pleistocene temperature depression and vegetation change in Ecudaorian Amazonia. Quaternary Research 34: $330-345$

ENGELhaRDT, H. 1895. Über neue Tertiärpflanzen Sud-Amerikas. Abhandlungen der Senchenbergischen Naturforschenden Gesellschaft Bd. 19: $1-47$.

GENTRY, A. H. 1982. Neotropical floristic diversity: phytogeographical connections between Central and South America, Pleistocene climate fluctuations or an accident of the Andean orogeny? Annals of the Missouri Botanical Garden 69: 557-593.

Giraud, B., AND A. LEJAL-NiCOL. 1989. Cassinium dongolense n. sp. bois fossile de Caesalpiniaceae du Nubien du Soudan septentrional. Review of Palaeobotany and Palynology 59: 37-50.

GoldBLATT, P. 1993. Biological relationships between Africa and South America: an overview. In P. Goldblatt [ed.], Biological relationships between Africa and South America, 3-15. Yale University Press, New Haven, CT.

GraHam, A. 1992. Utilization of the isthmian land bridge during the Cenozoic-paleobotanical evidence for timing and the selective influence of altitudes and cliamte. Review of Palaeobotany and Palynology 72: 119-128.

GREEN, D. S. 1980. The terminal velocity and dispersal of spinning samaras. American Journal of Botany 67: 1218-1224.

Herendeen, P. S., W. L. Crepet, and D. L. Dilcher. 1992. The fossil history of the Leguminosae: phylogenetic and biogeographic implications. In P. S. Herendeen and D. L. Dilcher [eds.], Advances in Legume systematics, part 4, The fossil record, 303-316. Royal Botanical Gardens, Kew.

Hooghiemstra, H. 1993. Paleoclimatic conditions around 3 million years BP: pollen evidence from Colombia. $\ln \mathrm{R}$. S. Thompson [ed.], Pliocene terrestrial environments and data/model comparisons, U.S. Geological Survey Open File Report 94-23: 31-37 (Abstract).

Hungerbühler, D., M. Steinmann, W. Winkler, D. Seward, A. Egüez, F. HELler, AND M. FORD. 1995. An integrated study of fill and deformation in the Andean intermontane basin of Nabón (Late Miocene), southern Ecuador. Sedimentary Geology 96: 257-279.

LAVIN, M., AND M. LUCKOW. 1993. Origins and relationships of tropical North America in the context of the boreotropics hypothesis. American Journal of Botany 80: 1-14.

Madden, R. H., R. Burnham, C. C. Swisher III, A. A. Carlini, and A. H. WALTON. 1994. Mammalian paleontology, paleobotany and geochronology of the Miocene intermontain basins of southern Ecuador. Journal of Vertebrate Paleontology 14(3): 35A

MANCHESTER, S. R. AND W. J. KRESS. 1993. Fossil bananas (Musaceae): Ensete oregonense sp. nov. from the Eocene of western North America and its phytogeographic significance. America Journal of Botany 80: 1264-1272.

Marshall, L. G. 1981. The Great American Interchange-an invasion induced crisis for South American mammals. In M. Nitecki [ed.], Biotic crises in ecological and evolutionary time, 133-229. Academic Press, New York, NY

- 1985. Geochronology and Land-Mammal biochronology of the Transamerican Faunal Interchange. In F. G. Stehli and S. D. Webb leds.], The great American biotic interchange, 49-85. Plenum, New York, NY.

Marshall, L. G., R. F. Butler, R. E. Drake, G. H. Curtis, and R. H. TEDFORD. 1979. Calibration of the Great American Interchange. Science 204: 272-279. 
Marshall, L. G., S. D. Webi, J. J. Sepkoski, and D. M. Raup, 1982. Mammalian evolution and the Great American Interchange. Science 215: $1351-1357$

Menendez, C. A. 1969. Die fossilen floren Südamerikas. In E. J. Fittkau, J. Illies, H. Klinge, G. H. Schwabe, and H. Sioli [eds.], Biogeography and ecology in South America, vol. 2, 519-561. Junk, The Hague.

Muller, J. 1981. Fossil pollen records of extant angiosperms. Botanical Review 47: 1-146.

Plumstead, E. P. 1961. Fossil floras of Antarctica. Trans-Antarctic Expedition 1955-1958, Scientific Reports No. 9: 1-132.

Polhill, R. M. 1981. Dalbergieae. In R. M. Polhill amd P. H. Raven [eds.], Advances in Legume systematics, part, I, 233-242. Royal Botanic Gardens, Kew.

Polhill, R. M., P. H. Raven, and C. H. StiRton. 1981. Evolution and systematics of the Leguminosae. In R. M. Polhill and P. H. Raven [eds.], Advances in Legume systematics, part I, 1-26. Royal Botanic Gardens, Kew.

RaVen, P. H., AND D. I. AxELrod. 1974. Angiosperm biogeography and past continental movements. Annals of the Missouri Botanical Garden 61: 539-672.

ROMERo, E. J. 1986. Paleogene phytogeography and climatology of South America. Annals of the Missouri Botanical Garden 73: 449461.

. 1993. South American Paleofloras. In P. Goldblatt [ed.], Biological relationships between Africa and South America, 62-84. Yale University Press, New Haven, CT.

- AND L. J. HickEY. 1976. A fossil leaf of Akianaceae from Paleocene beds in Argentina. Bulletin of the Torrey Botanical Club 103: $126-131$

Rudd, V. E. 1974. A résumé of the genus Tipuana (Leguminosae). Phytologia 28: 475-478.

RundelL, P. W. 1989. Ecological success in relation to plant form and function in the woody legumes. In C. H. Stirton and J. L. Zarucchi [eds.], Advances in Legume Biology, Monographs in systematic botany, 377-390. Missouri Botanical Garden, St. Louis, MO.

SEwarD, A. C. 1931. Plant life through the ages. Cambridge University Press, Cambridge.
SpJut, R. W. 1994. A systematic treatment of fruit types. Memoirs of the New York Botanical Garden, 70: 1-181.

Stehl, F. G., AND S. D. WeBB. 1985. A kaleidoscope of plates, faunal and floral dispersals, and sea level changes. In F. G. Stehli and S. D. Webb [eds.], The great American biotic interchange, 3-16. Plenum, New York, NY.

TAYloR, D. 1991. Paleobiogeographic relationships of Andean angiosperms of Cretaceous to Pliocene age. Palaeogeography, Palaeoclimatology, Palaeoecology 88: 69-84.

VAN DER HAMMEN, T., AND M. L. ABSY. 1994. Amazonia during the last glacial. Palaeogeography, Palaeoclimatology, Palaeoecology 109: 247-261.

VRBA, E. S. 1993. Mammalian evolution in the African neogene and a new look at the Great American Interchange. In P. Goldblatt [ed.], Biological relationships between Africa and South America, 393434. Yale University Press, New Haven, CT.

WendT, T. 1993. Composition, floristic affinities and origins of the canopy tree flora of the Mexican Atlantic Slope rain forests. In $\mathrm{T}$. P. Ramamoorthy et al. [eds.], Biological diversity of Mexico: origin and distribution, 595-680. Cambridge University Press, New York, NY.

Wuninga, V. M., AND P. Kuhry. 1990. A Pliocene flora from the Subachoque Valley (Cordillera Oriental, Colombia). Review of $\mathrm{Pa}$ laeobotany and Palynology 62: 249-290.

Winkler, W., A. Eouez, D. Seward, M. Ford, F. Heller, D. HungerBUHLer, ANd M. STEInMANn. 1993. A short-lived compression related sediment fill in the Andean Intermontain Basin of Nabón (Late Miocene, Southern Ecuador). Symposium International "Geodynamique Andine," Oxford (UK): 321-324.

WOLF, T., AND G. VOM RATH. 1876. Geologische untersuchung der provinz Loja. Zeitschrift Deutsch Geologishe Gesellschaft Bd. 28: 391-393.

Wyss, A. R., J. J. FlynN, M. A. Norell, C. C. Swisher III, R. Charrièr, M. J. NovaceK, and M. C. MCKenna. 1993. South America's earliest rodent and recognition of a new interval of mammalian evolution. Nature 365: 434-437.

ZamaloA, M. Del C., AND E. J. Romero. 1990. Some spores and pollen from the Cullen Formation (Upper Eocene to Middle Oligocene), Tierra del Fuego, Argentina. Palynology 14: 123-133. 